\title{
Transnational collective agreements and the development of new spaces for union action: the formal and informal uses of International and European Framework agreements in the UK \\ Dol:
}

10.1111/bjir.12244

\section{Document Version}

Accepted author manuscript

Link to publication record in Manchester Research Explorer

\section{Citation for published version (APA):}

Mustchin, S., \& Martinez Lucio, M. (2017). Transnational collective agreements and the development of new spaces for union action: the formal and informal uses of International and European Framework agreements in the UK. British Journal of Industrial Relations, 55(3), 1-25. https://doi.org/10.1111/bjir.12244

\section{Published in:}

British Journal of Industrial Relations

\section{Citing this paper}

Please note that where the full-text provided on Manchester Research Explorer is the Author Accepted Manuscript or Proof version this may differ from the final Published version. If citing, it is advised that you check and use the publisher's definitive version.

\section{General rights}

Copyright and moral rights for the publications made accessible in the Research Explorer are retained by the authors and/or other copyright owners and it is a condition of accessing publications that users recognise and abide by the legal requirements associated with these rights.

\section{Takedown policy}

If you believe that this document breaches copyright please refer to the University of Manchester's Takedown Procedures [http://man.ac.uk/04Y6Bo] or contact uml.scholarlycommunications@manchester.ac.uk providing relevant details, so we can investigate your claim.

\section{OPEN ACCESS}




\title{
Transnational Collective Agreements and the Development of New Spaces for Union Action: The Formal and Informal Uses of International and European Framework Agreements in the UK
}

\author{
Stephen Mustchin and Miguel Martínez Lucio
}

British Journal of Industrial Relations (2017 - AAM)

\begin{abstract}
Transnational collective agreements (TCAs) are an important development in the international dimension of industrial relations. This article compares four case studies of multinational companies in the UK covered by TCAs. Findings show that while the formal influence of TCAs was limited, they were invoked around particular disputes and could strengthen union influence in a context otherwise characterized by limited union rights. Such influence depended on the co-ordination of workplaceand firm-level industrial relations institutions, union access to management at headquarters level and union receptiveness to and outward engagement with transnational activity. The formal but also the informal dimensions of these dynamics played a significant role.
\end{abstract}

\section{Introduction}

The internationalization of labour relations is a growing area of study. Transnational Collective Agreements (TCAs), encompassing International Framework Agreements (IFAs) and European Framework Agreements (EFAs) constitute a new set of co-ordinating mechanisms and institutions in the international regulation of employment. This article examines how trade unions at various levels within the UK use and reference such agreements, both inwardly facing (how these agreements impact on industrial relations within multinational company (MNC) subsidiaries) and outwardly facing (how UK-based unions engage with wider international campaigns supported by international trade union organizations).

Our analysis focuses on four cases of transnational industrial relations in the UK: Volkswagen-Bentley, Santander, G4S and Unilever. Representing different sectors (manufacturing and services) and forms of ownership (UK and non-UK headquartered), each features some degree of union-management engagement and collective agreement at transnational level, but demonstrated differing outcomes dependent on the receptiveness of unions to transnational agreements, their levels of outward engagement with transnational networks and the interaction between workplace- and firmlevel industrial relations institutions, company headquarters and international unions and campaigns. The cases with more co-ordinated workplace- and firm-level level industrial relations institutions, Volkswagen-Bentley and G4S, featured more unified union organization in the UK with stronger formalized links with European Works Councils (EWCs) and Global Union Federations (GUFs) and more robust, formalized IFAs, whereas multi-unionism, weaker

agreements and less formalized engagement with international employee representation featured in the less co-ordinated cases of Santander and Unilever. A key difference was whether unions had indirect forms of access to headquarter management via international networks, EWCs or GUFs (as in Volkswagen-Bentley and Santander), or direct (as in G4S and Unilever). The cases demonstrate how the influence of labour, or its capacity to persuade or force employers to act in ways that they otherwise would not (Brookes 2013: 182), could be strengthened by TCAs in contexts otherwise 
characterized by limited union rights. This was evident at specific junctures when elements of apparently dormant TCAs were invoked and referenced. In all the cases, TCAs served as a tool, albeit in varying and often informal ways, for strengthening union influence; however, unions were more able to derive leverage from these agreements where they derived additional power resources from workplace- and firm-level industrial relations institutions and had access to headquarter management.

Most TCAs make reference to generalized rights established through international labour standards including International Labour Organization (ILO) core conventions. The vagueness of such formal commitments may mean that their support for direct, enforceable rights is limited, as is their relevance to day-to-day industrial relations processes (Niforou 2012). However, more informal engagement with union and management networks within MNCs, and the invocation of rights established through otherwise dormant transnational agreements within specific local disputes, demonstrates the potential for TCAs to strengthen collective rights and rule-making processes (McCallum 2013: 13). The UK is a useful context for examining these dynamics, as collective agreements generally have a non-binding nature and informality (Clegg 1976; Terry 1977), freedom of association and the ability of unions to organize are demonstrably constrained, and breaches of labour standards and anti-union strategies are relatively common (Gall 2013).

The findings demonstrate how, superficially, a dismissive view of such agreements may be justified, with rights deriving from TCAs difficult to enforce, but empirical 'patience' and closer ethnographic investigations of informal processes reveals a plethora of relatively novel resources and possibilities for trade unions. This article argues that, first, TCAs can in certain circumstances strengthen union influence in contexts otherwise characterized by limited union rights, like the UK, via improved networking among worker representatives and international engagement. This networking and engagement could help unions to gain information and invoke transnational agreements that strengthened bargaining and union influence more locally. This influence was manifested in a variety of forms but was predominantly informal, characterized by features of soft regulation and differing relationships with management at various levels. Some strengthened influence, albeit to variable extents, was apparent in all four of the cases. Second, there were, however, significant variations in outcomes from this changed level of influence, and unions were able to make more substantive gains for workers where they had stronger power resources across two main dimensions: union access to headquarters-level management; and the level of co-ordination of workplace- and firm-level industrial relations institutions and trade union organization. Analysing these less obvious outcomes of TCAs requires careful qualitative scrutiny of workplace relations and how workplace- and firm-level actors used and referenced such agreements.

\section{TCAs, their local impact and internationalism}

Labour relations are becoming more internationalized as a consequence of capital mobility, the role of MNCs and their effects on national and transnational institutional configurations (Whittall 2010). Optimism regarding the potential of transnational institution-building and agreements is countered by analysis that questions the value of TCAs in establishing formal, enforceable rights across MNCs. The emergence of TCAs since the 1980s has been driven by three interrelated developments: the changing nature of union internationalism; the emergence of corporate social responsibility (CSR) policies and voluntary regulation within MNCs; and the evolution of European industrial relations including some degree of transnational regulation at EU level and the establishment of EWCs (Stevis and Boswell 2007). Notably, 267 TCAs have been identified including 140 IFAs, with the remainder largely consisting of EFAs (Rehfeldt 2015). Such agreements establish GUFs, EWCs, Global Works Councils (GWCs), national and regional labour organizations as actors within a more internationalized industrial relations environment, promote company-level agreements to regulate supply chains and 
make explicit linkages between company-level agreements, ILO conventions and other multilateral instruments such as the UN Global Compact and the OECD Guidelines on MNCs (Hammer 2005). The role of labour organizations within these agreements provides greater legitimacy than in more unilateral codes of corporate conduct (Schömann et al. 2008: 114).

TCA has been used as a term encompassing IFAs (which have a global scope and a central role for GUFs), along with EFAs (with a regional focus but similar institutional configurations and principles.) EFAs are more likely to have EWCs rather than GUFs as the most significant employeeside actor; nonetheless the principles and usually the content of both IFAs and EFAs are generally very similar, allowing for wider comparisons of multi-level forms of worker representation and how they organize around TCAs. As worker and union rights are increasingly constrained at the national level, transnational labour co-operation involves 'governance struggles' seeking to establish new rules of engagement that enable workers to exercise power, with TCAs forcing MNCs to engage with unions and wider labour standards (McCallum 2013: 11-14).

More 'optimistic' analyses argue that EWCs support new forms of regulation and cultures of engagement, solidarity, learning and use of social media, with significant influence in cases where resources and union internationalism are more advanced (Whittall et al. 2009). However, some analyses are dismissive of company-specific representation through EWCs, arguing that it rarely modifies major corporate decisions, focuses on information and consultation rather than bargaining, suffers from inconsistent coverage and high levels of management control and is often symbolic unless backed by strong, well-resourced trade unions with the capacity to challenge management decisions (Waddington 2011; Wills 2000). EWCs have been criticized for protecting the interests of EU workers, particularly in wealthier member states, at the expense of workers elsewhere (Banyuls et al. 2008; McCallum 2013: 42).

These debates on the limitations of EWCs draw parallels with those on TCAs, which are mostly underutilized and rarely used in a meaningful way (McCallum 2013: 43). This poor record of implementation has been linked to their emphasis on corporate-level social partnership with inadequate mobilization of more local unions (Fichter and McCallum 2015: 80). IFAs may be weakly understood by national and local unions, who may not be affiliated to GUFs, and the non-binding nature of IFAs and management hostility, indifference and reluctance to promote their content within their subsidiaries and supply chains are further limitations (Fichter and Helfen 2011; Niforou 2012; Stevis 2011).MNCs with TCAs display marked variation in terms of information and consultation practices, training related to TCA content and the utility of TCAs in challenging local employment practices or abuses of labour standards (Sydow et al. 2014: 494-5). Scepticism towards IFAs has increased in recent years, with both national and global union organizations criticizing their weaknesses and problems in enforcing them (Fichter and McCallum 2015: 70; McCallum 2013: 44). While the international union movement is less divided than during the cold war, problems remain regarding the privileged position of larger unions in wealthier countries, GUF relationships with unions more locally and resource constraints in a time when some national unions are pulling back from international engagement due to challenges faced at national and local levels (Croucher and Cotton 2011).

While acknowledging these limitations, there is evidence of stronger, more strategically coordinated examples of TCAs in the motor, shipping and hospitality industries, and instances of IFAs supporting organizing in both developing countries and neoliberal institutional contexts where unions are weaker (Anner et al. 2006; Gregoratti and Miller 2011; Helfen and Fichter 2013). Questions remain regarding the circumstances in which unions are more or less successful in using TCAs to increase their influence and power resources within MNCs, especially in contexts where the industrial relations system is considered weaker. Where such approaches have been successful, international issues were integrated into and referenced in local union and workplace representative structures 
rather than constrained within higher level national or transnational institutions (Greer and Hauptmeier 2012: 283). The impact of such agreements is dependent on relationships and power dynamics between unions, works councils, EWCs and management at various levels, including access to and influence on headquarter management (Da Costa et al. 2012; Keune and Marginson 2013: 494; Williams et al. 2013).

Furthermore, in the absence of access to company headquarters or principles of comanagement, key individuals ('political entrepreneurs') within unions and works councils have used transnational institutions to strengthen their influence within MNCs, but this is often based on more informal networks that develop strategies beyond the formal contents of agreements and in line with wider employee representation strategies (Greer and Hauptmeier 2008: 91-3). The often generic content of TCAs means that their role in establishing formalized rights for workers in MNCs is limited. However, they can strengthen procedural rights where workplace- and firm level trade unions are receptive to such agreements and invoke them at specific moments, which can indirectly strengthen union recognition and local bargaining within national institutional contexts like the UK that otherwise offer limited support for such processes.

Informality has been a salient feature of the British industrial relations debate, given the historically voluntarist nature of collective agreements, periods of heightened bargaining at workplace level and the importance of informal understandings, practices and even oral agreements (Clegg 1976: 56-7; Terry 1977). National collective agreements covering diverse employers and workplaces could not establish formal rules governing the detail of workplace industrial relations, with informal bargaining and local interpretation of wider agreements filling this 'vacuum' (Terry 1977: 77). The wider relationship between the formal clauses of TCAs and their inward influence on more informal, workplace- and firm-level industrial relations and bargaining resonates with these earlier debates. The historical weakness of collective agreements in the UK necessitates a high level of sensitivity to local, informal dynamics within the employment relationship. The analysis below applies such principles to TCAs as generalized agreements in a weakly regulated institutional context which nonetheless frame and influence more informal industrial relations dynamics and uses of TCA clauses.

Non-formal relations at the local level can underpin the effectiveness - or otherwise - of formal and structured systems of dialogue and representation (Oxenbridge and Brown 2002). The importance of personal relations and networks within and between unions and other social actors mirrors wider debates about the nature of networks and their various formal and informal features (Darlington 2002; Jensen 2004). More recently, Joyce (2016) has argued (drawing on Batstone et al. 1977) that local union representatives can maintain informal influence at workplace level, even where bargaining scope is limited within highly controlled production processes. Understanding the subtlety of roles and relations - linked to notions of worker representatives as potential political entrepreneurs and organizational networkers in various forms - is essential for evaluating the role of informal and more discreet spaces within industrial relations, and how these diverse actors actually engage with formal bodies of rules and regulations at different moments. Hence, TCAs can serve an important role in strengthening local union power and facilitating cross-border networks (Fichter and Helfen 2013), creating an arena within which wider issues can be invoked beyond the formal content of agreements.

The theoretical framework informing the analysis below builds on debates highlighting the importance of wider formal and informal co-ordination processes between industrial relations actors at various levels (Keune and Marginson 2013; Pulignano 2005; Williams et al. 2013), resonating with debates over EWCs that focus on such exchanges, informal supports and new forms of communication (Knudsen et al. 2007; Martínez Lucio and Weston 1995, 2000; Pulignano 2009). An important dynamic within this context is that of different forms of power, including institutional power (the extent that unions are able to derive resources from the ostensibly more formalized status 
they gain through negotiating TCAs) and associational or coalitional power (the extent to which local and national unions are able to forge links with unions in other countries, EWCs, GUFs and other potential allies) (Brookes 2013: 191; Fichter and McCallum 2015: 67). This element of our theoretical framework builds on this interest in the informal, developing greater understanding of the links between rights established through TCAs and power resources deriving from them, including more informal and indirect uses of rules derived from TCAs to challenge corporate decisions and compel employers to change their actions. Analysis of power within this context necessitates a greater sensitivity to questions of union organization around 'softer' forms of regulation, including how regulation and rules are referenced and used in weakly regulated environments such as the UK, as well as their impact on outward-facing union activity within spaces that link to wider campaigns and struggles (Martínez Lucio and Weston 2000).

The analysis below therefore addresses the following overarching research question: what factors influence UK unions' capacity to leverage TCAs to gain influence within MNCs (at local level and internationally)? The four cases show how different strategies, institutional configurations and power resources impact on collective bargaining, union influence and wider corporate behaviour. This article examines the intersection of both workplace and firm-level union organization and union access to corporate headquarters, and how these two factors determine the form union influence takes. The inter-relationship between formal institutions and agreements, more informal union engagement with transnational networks, and more ad hoc invocation of elements of TCAs around particular disputes allows for a richer, more nuanced assessment of TCAs and their impact on union influence. These dynamics need to be understood in relation to the way such relations are configured in terms of their receptive components - as in the way TCAs are used locally and help reconfigure unionmanagement relations - and the outward looking component - the way they contribute to international union activity and strategy. These two dimensions are reflected in the analysis below where we argue how these features are important not just for more institutionalized, stronger cases but also in less co-ordinated cases where unions appear to hold less institutional influence.

\section{Research Methods}

The research discussed below was part of a wider comparative research project conducted between January 2014 and January 2015 (Leonardi 2015). This was led by the Confederazione Generale Italiana del Lavoro (CGIL) in Italy and involved academic institutions, labour research consultancies and trade union research centres from Italy, Spain, UK, Germany, France, Poland and Bulgaria. The research focused on the local implementation of TCAs including European-level agreements and IFAs, predominantly focusing on the financial services and metalworking sectors. Comparative research was carried out in seven MNCs, with over 50 interviews triangulated with documentary analysis and participation in three international practitioner and academic workshops (Leonardi 2015). This allowed for analysis of the process of negotiating such agreements, their impact within more local environments and MNC subsidiaries, the contribution of agreements to more general processes of social dialogue and examples of critical points where TCAs were invoked within local negotiations and bargaining processes. This common framework and set of themes was used in the comparative cases in the full report and applied to two additional cases in the UK. This context is of particular interest given the contrast between the typical content of TCAs regarding freedom of association, union recognition and other collective rights, and the weaknesses of the wider regulatory framework supporting such processes in the UK. The authors conducted research in the UK subsidiaries of Volkswagen and Santander as part of this overall project, expanding this work concurrently with two additional case studies (G4S and Unilever). The data were analysed inductively using templates informed by broader project findings and close analysis of the wider literature. 
The four UK cases consisted of 20 extended interviews in total; each case drew on interviews with an HR manager, one national union official, one GUF representative and two union representatives with involvement in EWCs or international union activity interviewed per case. In G4S a management interview was not forthcoming and was substituted with a further national union official, and interviews with Bentley management from another recent study by the authors supplemented these data. While the diversity of the cases presents methodological challenges in terms of analysis, they also allow for an assessment of different forms of multi-level employee representation within MNCs, institutional differences and the nature of power resources in particular contexts. The cases include four MNCs in the UK; two UK-headquartered firms (G4S and Unilever) and two overseas firms (Santander and Volkswagen); two with an IFA (G4S, Volkswagen) and two with an EFA (Santander, Unilever); and two each in services (G4S, Santander) and manufacturing (Volkswagen, Unilever).

The cases all have some form of transnational agreement but varied significantly in terms of the nature of agreements, workplace- and firm-level union power resources, union access to headquarter management, union receptiveness to TCAs and their outward engagement with international union institutions and networks. This supports comparative analysis of how TCAs influence local industrial relations and union engagement with internationalism. Demonstrating causality is complex, especially within qualitative research focused on comparative case studies such as this. However, if one was to invoke broadly positivist-influenced terminology, differing levels of union influence would be the dependent variable, with: the more-or-less coordinated nature of workplace- and firm-level industrial relations institutions, including union organization; the unioncorporate headquarters relationship; and levels of engagement with international worker representative networks as the three main independent variables to be analysed. Causal relationships in general terms between agreements and local industrial relations are highlighted by this analysis, allowing for judgements to be made regarding the conditions under which TCAs can strengthen union influence at firm and workplace levels. A key issue within the research process was that initially, the agreements seemed to have limited influence, but closer, qualitative enquiry of these diverse actors across time uncovered a range of novel changes in terms of union activity and resources, shifting relationships with management and combinations of campaigning and more institutionalized approaches to industrial relations within MNCs.

\section{Case studies - overview}

The descriptive characteristics of the four cases are set out in Table 1, and are of interest because they are located within the context of a neoliberal economy: the United Kingdom, where institutional support for unions generally is weak and internationalism likely to be less institutionally supported locally, with the impact of change being externally oriented. Yet, within this context notable variations emerge deriving from firm-level industrial relations, the nature of institutional union coordination structures and their strengths and weaknesses. This article argues that more informal influence and networks can sometimes override such limitations, especially when the MNC is headquartered locally. Additionally, multi-unionism featuring divisions and more conservative employee representative bodies can militate against the development of outward facing activity and internationalism. A key finding from the wider comparative research was that, despite difficulties in enforcing 'rights' or the substantive content of such agreements, particularly where unions were weaker as in the Eastern European cases and parts of the financial services sector, more informal developments supporting elements of social dialogue were emerging that created opportunities for unions more locally in terms of bargaining, consultation and institutional influence (Leonardi 2015: $51-3)$. 
TABLE 1: Overview of Case Studies

\begin{tabular}{|l|l|l|l|l|l|}
\hline MNC & Sector & Headquartered & TCA & $\begin{array}{l}\text { Global } \\
\text { workforce (UK } \\
\text { workers) }\end{array}$ & $\begin{array}{l}\text { UK Union } \\
\text { membership } \\
\text { density }\end{array}$ \\
\hline $\begin{array}{l}\text { VW } \\
\text { Bentley }\end{array}$ & Manufacturing(automotive) & Germany & IFA & $593,000(4,000)$ & $90 \%$ \\
\hline Santander & Services(financial) & Spain & EFA & $186,000(20,000)$ & $50 \%$ \\
\hline G4S & Services(security) & UK & IFA & $623,000(37,000)$ & $24 \%$ \\
\hline Unilever & Manufacturing(food/chemicals) & $\begin{array}{l}\text { UK/ } \\
\text { Netherlands }\end{array}$ & EFA & $172,000(7,000)$ & $33 \%$ \\
\hline
\end{tabular}

The first case is Bentley Motors, a subsidiary of Volkswagen since 1998, and the most formalized and advanced of the four cases in terms of trade union organization, the integrated nature of its GWC and associated IFAs. A range of TCAs have been developed in Volkswagen; German trade unions pushed for such agreements so as to raise standards more generally and avoid job losses in the firm's home country. The first TCA was signed in 2002, a general Social Charter covering ILO conventions relating to freedom of association, minimum wages, limits to working time, prohibiting child labour and a 'spirit of cooperative conflict management and social commitment ... [to] the security and development of employment opportunities'. Agreements have also been signed on Health and Safety (2004), Sustainability and Supplier Relations (2006), Labour Relations, including employee codetermining structures (2009), and Temporary Agency Work, minimizing the use of agency workers and giving them the same rights as salaried employees (2012). These agreements were led by the GWC with support and further ratification by the GUF IndustriALL.

The other three cases were much less institutionally and internationally coordinated. The second case, Santander, was formed following acquisitions by the parent company of three UK building societies (Abbey National, Bradford and Bingley and Alliance and Leicester). Historically, the first two of these had internal staff associations which gained independent union status in 2001/2, with the Alliance and Leicester union amalgamated into the Communication Workers Union (CWU) and the Abbey National staff association converted into the Advance trade union. Union organization varied considerably with very high union membership density in some (typically larger) establishments but minimal presence in others. The three TCAs within Santander, applicable to all subsidiaries in Europe, consist of joint management-EWC declarations relating to: Equal Treatment of Women and Men (2008), a short two-page declaration making broad commitments to promote equal treatment of and opportunities for men and women in terms of promotion, work-life balance and prevention of sexual harassment; Social Rights and Labour Relations (2009), based on 'permanent social dialogue and ... cooperative relations with the representatives of all the employees', committing the firm to respect ILO conventions regarding freedom of association and 'union freedom', social dialogue, equal opportunities, freedom of employment choice and 'rejection of child labour', training promotion, commitments to adhere to legal norms regarding working time and pay, security of employment and avoidance of compulsory redundancies and promoting workplace health. The 2011 Provision of Sustainable Financial Services agreement followed a campaign by the finance section of the GUF UNI-Global, and is a joint EWC and management declaration focusing on provision of 'responsible, sustainable financial services' that are not distorted by performance management regimes that encourage mis-selling; this agreement is linked to the firm's wider CSR policy. A general, voluntary Code of Conduct unilaterally devised by central management had a more global scope, and following the 2009 agreement, clauses on freedom of association and other working 
conditions were integrated into this wider voluntary instrument. These agreements were made via the EWC within Santander, established in 2005 following pressure on the firm from the CC.OO union in Spain.

The third case, G4S, focuses on security and outsourcing. Campaigns driven by unions and other civil society organizations focusing on, inter alia, the treatment of people within its custody, its business practices and provision of services to authoritarian regimes, have damaged the firm's image; the company now places a heavy rhetorical emphasis on the need to 'transform our culture' through 'implementing a fundamental programme of corporate renewal'. Prior to 2008, a five-year campaign by the Service Employees International Union (SEIU) in the US focused on organizing staff in the security industry and private prisons in the face of anti-union management. This work was expanded through UNI-Global into a global corporate campaign supporting G4S workers in Southern Africa and South Asia and calling for divestment in the firm (McCallum 2013). This culminated in a complaint to the UK OECD contact point, highlighting problems associated with subsidiary management outside the UK not engaging with unions (Helfen and Fichter 2013). A relatively formalized institutional framework for transnational worker representation was established through the IFA co-signed in December 2008 by UNI-Global, G4S and the GMB. This 'Ethical Employment Partnership' claims that these three organizations 'respect fundamental human rights, both in the community and at the workplace, and agree to work together to raise employment standards throughout G4S and the wider market'. Applicable to all firms owned or controlled by G4S, the IFA commits the firm to respect the ILO's core conventions and minimum employment standards globally. Freedom of association, union membership and representation rights are supported by the agreement, with local managers ordered not to oppose unionization and to allowaccess by unions affiliated to UNI-Global. Parties to the agreement are entitled to call for review meetings in cases of disputes, with G4S committed to discipline managers who breach the agreement. Globally, G4S had agreements with 72 different unions but membership levels varied across the firm's international operations and large swathes of employees were without representation.

The final case, Unilever, places a heavy emphasis on sustainability, ethics and CSR, partly in response to publicized examples of environmental degradation and the abuse of worker and union rights in some of its subsidiaries. The main formalized transnational agreements within Unilever were established in the EWC's 'Barcelona Agenda', signed in September 2013. Driven in large part by imperatives to consult over cross-European restructuring processes, this commitment to the 'European-level objective of ensuring sustainable employment' includes agreements on: diversity and equal opportunities, workplace health and a commitment to 'socially responsible restructuring'. In the UK, these agreements had a modest impact, but while this is the weakest set of TCAs analysed here, UK unions and key individual activists played a notable role in wider transnational activity, both within the EWC and the GUF.

The section that follows focuses on the receptiveness of unions in the UK to TCAs and internationalism, and how these developments impacted on both union-management relations and collective bargaining. This is followed by analysis of outward-facing activity, including union involvement in formalized transnational structures as well as less formal forms of networking and campaigning. The four diverse cases allow for an assessment of how workplace- and firm-level union organization, union access to corporate headquarters and different institutional configurations determine the capacity of unions to gain leverage within international industrial relations processes as well as the potential for (and constraints on) outward engagement with internationalism. 


\section{Union receptiveness to TCAs - local agreements, outcomes and the inward influence of international developments}

\section{Management-Union Relations, TCAs and Local Agreements}

In terms of more informal developments and changes in industrial relations climate that were influenced by transnational dynamics, the structure of management and the institutional position of unions had shifted notably in some cases, particularly in the non-UK headquartered VW-Bentley and Santander. Following the Volkswagen takeover of Bentley, some senior managers were removed with German HR managers, senior executives, finance and engineering staff introduced. A more consultative, participative and less confrontational management strategy was apparent although this fell short of German-style co-determination, which union interviewees were sceptical of anyway. These changes marked a shift from the previous regime of UK-led management which was seen to be more hierarchical and combative in some ways yet also more inclusive in others:

'there was . . . a hierarchy of poshness, aristocracy, whatever you like to call it - within the hierarchy of the management, but most managers worked their way up from the shop floor; and that had its appeal because everybody saw an opportunity.' (Unite shop steward)

The changes were seen as part of a more systematic, strategic and inclusive approach to unionmanagement relations although there were limitations;

'Since Volkswagen have taken over we've got this stability because they're very highly recognised [in their approach] . . I'm not saying [the previous management] were anti-union but depending on which way the wind blew you had to be careful . . . old [union] convenors ... had to wait outside an office just to get an audience with the personnel director.' (Unite shop steward)

In Santander, while the specific content of the TCAs were seen as having a limited effect, the 2009 Social Rights and Labour Relations agreement was felt to acknowledge the legitimacy of unions within the firm in contrast to management's approach prior to the takeovers, where non-union staff associations had historically been dominant and unions de-recognized in Alliance and Leicester in 2006. UK management were generally not felt to be 'doing what they're doing because of Spain', and a management respondent felt that 'in the UK there is no implication of any of this' regarding the EWC, but a relatively more consultative style of management closer to the relationship between MNC headquarters and the Spanish CC.OO had been cultivated. If local managers attempted to make unilateral changes, unions could refer them to senior HR who would insist on consultation, and these processes were seen as being to some extent embedded in management culture:

'. . . they do seem to bend over backwards to consult us on everything, which is not necessarily to say that they always take notice of us but if we say no then they'll come back with a revised proposal, they won't just say 'well sod you we're going to implement." (CWU national officer)

In G4S, the GMB had faced de-recognition threats in the past and were concerned to maintain representation within the firm. They had become the main national union signatory to the IFA; the SEIU had withdrawn from international work in G4S as their considerable investment in the campaign led to minimal membership growth in the US:

'. . . there was a lot of mudslinging at the time, backwards and forwards . . between the company and UNI-Global. We were a little bit like the intermediaries, the union that they 
knew best of all, because obviously we were the home based union, and we got involved on the basis of being the broker if you like.' (GMB national officers)

The institutional structures established around international work notably strengthened the position of the EWC and the GMB at the level of the firm's European operations, but without the more seemingly confrontational organizing approach adopted by the SEIU and UNI-Global in the earlier stages of the campaign. The GMB viewed this approach as a threat to employment levels and well-established recognition and bargaining rights that the union held (McCallum 2013: 87-8), demonstrating tensions in terms of contrasting strategies and arguably a focus more on protecting the conditions of workers in the areas where the GMB and the EWC had some jurisdiction as opposed to the more expansive, if ultimately unsuccessful, aims of the wider global campaign within G4S.

TCAs had a limited impact on UK-level union-management relations within Unilever, reflecting the plant-level bargaining that was prevalent and the limited role of union representation within formal institutional structures such as the EWC. There was a broad UK-wide collective agreement, but most conditions were negotiated at workplace level with headquarters maintaining tight control over remuneration. Increasingly, there were moves towards more individualized pay setting and performance management. Internal league tables were displayed in factories comparing production rates across the group, further fostering this sense of competition between workplaces. There had been some integration of the TCA signed by the EWC into UK level company policies and agreements, most notably within their equalities and mental health and well-being programmes. Retraining and redundancy pay exceeding the statutory minimum were secured in part due to the European agreement on restructuring. The limitations of the EWC emphasis on consultation were acknowledged; for example, the outsourcing of facilities management across the firm was implemented without consultation with the EWC informed only 24 hours before the changes were made public: 'They certainly take on board what's said but does it have the influence to change? I would doubt whether the Works Council has that much influence. If it's a corporate decision then it's a decision'. (Unilever EWC representative)

In terms of more informal dynamics, in VW-Bentley and Santander the more consultative nature of industrial relations in their home countries combined with TCAs created a structure within which local, conflictual management orientations could be challenged. However, TCAs had little impact on collective agreements within Santander, and within G4S and VW-Bentley it was felt that the IFAs did not significantly strengthen union rights beyond the existing content of local agreements. For example, in VW-Bentley, the 2012 Temporary Agency Work agreement:

'. . . didn't really impact much here, because some of the issues we'd dealt with. We're already organising trade unions . . . some of my other colleagues from round the world were embracing it, [as] one of the best things we've ever seen.' (Unite shop steward)

Similarly, in G4S, ' . . . the GMB's involvement in this was not for the fact that it was really going to change anything for us in the UK, because there's nothing in that agreement that we hadn't already got' (GMB national officers). While TCAs in general did not add significantly to the content of collective agreements in the UK context, they indirectly contributed to varying degrees towards a more consultative management culture and stable union recognition. This was highly significant in both G4S and workplaces acquired by Santander, where de-recognition had been threatened in the past, and the more consultative approach within VW-Bentley contrasted markedly with that prior to the takeover. Additionally, the agreements were referenced and invoked around particular issues and disputes, which is turned to next. 


\section{The Use of TCAs in Negotiations}

Although the impact of TCAs on establishing rights appeared limited on initial inspection, they helped to frame local agreements and developments relating to their content. For example, in VW-Bentley, outcomes deriving from transnational union activity and IFAs included improved union access to recruit agency workers supported by the 2012 Temporary Agency Work agreement, and changes to a proposal to develop a new model that was to be assembled in a Volkswagen plant outside the UK. Concerned to protect jobs, pressure was applied by the union locally with proposals taken to higher levels of the firm with the support of the GWC, which ultimately saw this new model being assembled in the UK plant, along with considerable recruitment of new employees.

In Santander, the invocation and referencing of TCAs around particular disputes was evident in some instances, although their concrete application had been problematic. In Isban, a wholly owned IT subsidiary within Santander that took over similar functions from within Alliance and Leicester, unions had been de-recognized in 2006. The management climate in such subsidiaries was reportedly more confrontational and the influence of the EWC, TCAs and a broadly consultative management ethos were less apparent. CWU recognition was re-established for most staff following the takeover in 2008, but a group of around 30 managers was transferred over without recognition. In negotiations in 2013, the 2009 agreement was raised by union negotiators, in an attempt to use the commitment to freedom of association as the basis for a recognition agreement for this group of staff, but the commitments were initially ignored by management. Recognition was ultimately secured on a voluntary basis but only following an initial approach to the Central Arbitration Committee.

In G4S within the UK, the IFA had been referenced in negotiations; for example, in Northern Ireland, local management attempted to force workers to pay for their own licenses and training, unlike in the rest of the firm's UK operations. Lengthy negotiations involved the GMB referencing the IFA and other agreements, with the payments required deemed to breach the agreement due to the unequal treatment that this group of UK workers would face. The dispute was settled following a meeting at G4S headquarters with the firm intervening to overrule the local management decision. While the IFA was thought to have a limited impact on employment conditions in the UK, and general awareness of the IFA among the workforce was low, this example:

'. . . was very important to demonstrate to our members, and our activists and our shop stewards and so on, that these agreements actually are worth something and they got something out of that global agreement. It's not all about international solidarity, it's about also what do we gain out of that? Does it deliver anything for us?' (GMB national officers)

The TCAs in Unilever were not generally viewed as providing rights that unions could deploy within negotiations, and the other examples given above demonstrate the limitations apparent when attempting to invoke principles such as freedom of association deriving from transnational agreements. They were, however, used in a way that allowed for pressure to be applied on the headquarters of MNCs. Rather than representing a 'hard' form of enforceable regulation, TCAs formed part of a repertoire of power resources that indirectly supported multi-dimensional union-employer dialogue, providing scope for further negotiation and to engage with headquarter-level management around more local disputes. In the three stronger cases (VW-Bentley, Santander and G4S), TCAs improved union-management relations and had some influence on the development of rules, if not rights, that unions could utilize. Where workplace- and firm-level industrial relations were more co-ordinated and held greater institutional power, as in VW-Bentley and G4S, pressure could be applied on corporate headquarters in order to settle disputes with TCA clauses invoked within such negotiations. Where unions were less co-ordinated, featuring multiunionism and less formalized international union and EWC relationships, as in Santander and Unilever, the impact on local industrial relations was weaker, 
although novel informal developments in terms of networking and campaigning respectively arose and enveloped various other activities within these otherwise more constrained firm-level institutional frameworks.

\section{The outward-facing dimension of union engagement with transnational industrial relations}

\section{EWCs and Formal Institutional Structures}

Having analysed the receptiveness of UK unions to TCAs, this section analyses their outward-facing activity. Formal transnational union influence varied across the four cases; in VW-Bentley and G4S, which had relatively coordinated firm-level union organization, this influence was stronger. However, in the less co-ordinated case of Santander, this created a space for the development of more informal international union networks, and in Unilever the less co-ordinated and institutionalized nature of international union activity created spaces within which more openly critical, campaigning approaches could be adopted with fewer risks in terms of losing institutional power resources.

The Unite branch at Bentley had visited the Volkswagen plant in Tennessee during the recent, highly controversial campaign for trade union recognition to support their US counterparts' organizing activity. The highly institutionalized nature of VW-Bentley meant there was generally less of an emphasis on corporate campaigning and struggles over institutional sources of power than in the other three cases. Similarly, in G4S, the IFA formalized and integrated the relationship between the EWC, UNI-Global, the IFA and national level trade unions to a greater extent than in many comparable institutional configurations. The IFA allowed the GMB and UNI-Global to apply pressure at headquarters level. Problems reported by UNI-affiliated unions were raised with central management by the GMB and in some cases the firm had investigated and replaced managers to ensure that the principles of the IFA were adhered to. The IFA was crucial to this as problems were overwhelmingly reported by the union side rather than regional managements. GMB and UNI-Global representatives, along with management, had jointly visited India, Colombia, Malawi and other countries where problems were reported, again informed by the principles of the IFA.

In Santander the CWU and Advance each had two representatives on the 13-member EWC. The CWU maintained an affiliation with UNI-Global, but Advance had disaffiliated as their influence and what they might gain was felt to be limited. The EWC itself met annually; a CWU EWC representative described the meetings as 'very stage managed, and it doesn't really help with the day to day industrial picture'. Discussions had taken place within EWC and GUF meetings relating to disputes in Italy over redundancies, strikes and disputes in Latin America, victimization of union activists in the US and other particular issues in subsidiaries, but co-ordinating action was seen as problematic and often not practically feasible. Attempts to encourage a more global IFA extending beyond the EU-level TCA had failed due to the firm's reluctance to agree to a more expansive agreement without the established legal basis held by EWCs and within the EU, and because of the considerable independence from MNC headquarters held by national subsidiaries. There was greater engagement with the EWC, the lead Spanish trade unions and international issues from the CWU in comparison to Advance, reflecting the CWUs wider, politically engaged orientation. Advance developed from a company staff association, with a partnership orientation focused on membership servicing and seemingly more sceptical as to the value of internationalism and cross-national solidarity. Differing union orientations inherited from predecessor firms constrained the development of international union networks within Santander.

The International Union of Foodworkers (IUF) was active in campaigning around labour rights within Unilever, and regular, non-binding meetings between the IUF and senior management following corporate campaigns provided a space for dialogue that had led to the firm treating these issues more seriously than before, although formal agreements to codify these approaches remained 
problematic. Institutional power was limited within Unilever, but this arguably created greater scope for campaigning work as there was less to be lost by taking a more openly critical approach. In Santander, the EWC worked with UNI-Global and national level unions, providing a basis for more informal networking and links between unions in different countries. This contrasts with VW-Bentley, where international work was highly formalized through the GWC. The G4S case was again highly formalized in some respects, but these institutional structures allowed for issues to be raised with the firm in arguably more effective, if less confrontational ways than was the case in the corporate campaigns organized by the SEIU prior to the GMB taking on a larger role.

\section{Networks and Informal International Activity}

In VW-Bentley, there was evidence of local trade unionists finding new roles and ways of referencing international developments due to the emerging spaces for transnational negotiation they could work within. Engagement with, for example, the Tennessee campaign, and informal links among representatives on the GWC had developed into a much broader form of engagement than that narrowly stipulated by the TCAs. In Santander, despite limitations in terms of institutional power and formal outcomes, the EWC and TCAs facilitated networks among union representatives in different countries that supported strengthened influence within the firm. Opportunities to share information and link up with trade unionists in other countries were valued; joint presentations to headquarter management from Spanish and UK EWC reps on key issues such as performance management and sales targets allowed for common concerns to be raised and addressed.

While arguably less focused on campaigning than earlier SEIU and UNI-Global organizing initiatives in G4S, the GMB was able to complement its UK activity as transnational worker representation created new reference points and capacity to exert influence. An example of these new forms of influence could be seen within pressure applied on the firm by unions in conjunction with the EWC regarding its operations in Israel supplying surveillance and security equipment. Many unions affiliated to UNI-Global were supportive of Palestinian solidarity work, and the issue was regularly raised at EWC meetings. This pressure, along with civil society campaigns and company concerns over reputational damage, had contributed to the firm withdrawing from their work in the region. The formal institutional framework created some leverage for the GMB to raise issues beyond the content of the IFA, including more informal negotiations and networking with unions in other countries.

In Unilever, international employee representation did not have a direct or major impact on the UK context but actors within the UK played a major role in applying pressure on the firm over a range of global issues beyond these formally less co-ordinated structures. The main UK representatives on the EWC were drawn from Unite, and Unite representatives also active within the IUF had used the national union forum within the firm to build support for transnational campaigns, demonstrating the importance of the UK-based union in wider transnational industrial relations and the role of key individuals or 'political entrepreneurs' (Greer and Hauptmeier 2008) in using available institutional structures to strengthen broader labour campaigning. Unilever's strategies on sustainability and CSR meant they were highly sensitive to reputational damage over breaches of these principles, which created opportunities to apply pressure on and secure changes from the firm. Global IUF campaigns on precarious work have targeted Unilever subsidiaries, and the presence of corporate headquarters in London meant that the UK was an important point where dialogue could be promoted and pressure applied. A major IUF-led campaign against precarious work commenced in 2009, building on campaigns in India and Pakistan referred to the UK OECD contact point in 2006/7, with the IUF working with a union organizing within Lipton Tea in Pakistan (where workers were overwhelmingly on casual contacts, unions were excluded and union activists victimized) and 
supported by national unions across Unilever's global operations (Croucher and Cotton 2011: 71-5). UK trade unionists were involved in promoting the campaign which involved mass emailing of senior executives, publishing articles on the case via the IUF and organizing global solidarity action. Eventually Unilever responded and made large numbers of the Pakistani workers permanent, with local agreements also secured in a number of other Indian and Pakistani Unilever plants to reduce precarious work and recognize unions. These wider principles were used to secure improved conditions in European, Canadian and Russian subsidiaries. This activity was independent of the TCAs in Unilever; unions were engaged in international activity but without the formalized status derived from TCAs seen elsewhere, providing a platform for international campaigning but with less to be lost in terms of institutional influence by taking a more publicly critical approach to international campaigns.

Less formal networks among workers engaged in international activity were a key development arising from the formal institutional architecture of, and communities of political entrepreneurs and activists linked to, TCAs and EWCs. The VW-Bentley case was highly formalized, as was G4S, which would be expected where relatively strong IFAs and institutional supports had been established. While the Santander agreement was less extensive, links had been developed between UK and Spanish unions at headquarter level, allowing for some pressure to be applied on the firm but without this being entirely conditional on the relative strength of the agreement. The less institutionalized nature of international worker representation in Unilever meant that the impact on industrial relations in the UK was more limited. However, new networks and spaces were created within which UK unions could engage in campaigns and solidarity work with less fear of jeopardizing the institutional structures that existed, mimicking to some extent the impact of TCAs in other cases.

\section{Discussion}

This research focuses on the relevance of international agreements and institutions within MNCs in order to determine what factors influence UK unions' capacity to gain influence in such firms, both locally and internationally. The findings analyse receptiveness (formal and informal managementunion relations and the impact of TCAs on local bargaining) and outward-facingwork, both through formal institutional structures and less formal networking. The differing nature of the cases allow for comparison of the impact of TCAs on union influence, deriving from the impact of more-or-less coordinated workplace- and firm-level industrial relations institutions, including union organization, union access to headquarter management and union engagement with international networks of worker representatives. TCAs were more effective as tools for strengthening union influence where unions could draw on other power resources, which resonates with the existing literature (e.g. Da Costa et al. 2012; Keune and Marginson 2013; Williams et al. 2013). However, a distinct finding of this research concerns how power resources deriving from strongly co-ordinated industrial relations institutions were in general necessary in order for unions to leverage both inward and outward influence (as in Volkswagen-Bentley and G4S), but that in situations where such institutions were less co-ordinated, unions could use their access to headquarter management in order to gain some degree of influence (as in Unilever).Where headquarter access was indirect and workplace- and firm-level industrial relations institutions were less co-ordinated, as in Santander, TCAs had a relatively limited impact on union influence within its UK operations more generally. Table 2 sets out some of the key comparative differences between the four cases. TCAs had a stronger impact in VW-Bentley and G4S than in the other two cases. This was achieved in different ways, so while the former case featured only indirect access to headquarter management, strong workplace level union organization formally linked to international networks and representative structures meant that union influence was relatively substantial. 
TABLE 2: Institutional Co-ordination, Headquarter Access and Union Influence

\begin{tabular}{|c|c|c|c|}
\hline \multicolumn{4}{|c|}{ UK union access to headquarter management } \\
\hline \multirow{3}{*}{$\begin{array}{l}\text { Workplace- } \\
\text { and-firm- } \\
\text { level } \\
\text { industrial } \\
\text { relations } \\
\text { institutions }\end{array}$} & & Indirect & Direct \\
\hline & $\begin{array}{l}\text { Less } \\
\text { coordinated }\end{array}$ & $\begin{array}{l}\text { Santander } \\
\text { - Limited inward TCA influence on } \\
\text { local agreements \& outcomes } \\
\text { - Limited outward influence on } \\
\text { international subsidiaries via } \\
\text { international union coordination }\end{array}$ & $\begin{array}{l}\text { Unilever } \\
\text { - Minimal inward TCA influence } \\
\text { on local agreements \& outcomes } \\
\text { - Moderate outward influence on } \\
\text { international subsidiaries via } \\
\text { international union coordination }\end{array}$ \\
\hline & $\begin{array}{l}\text { More } \\
\text { coordinated }\end{array}$ & $\begin{array}{l}\text { VW-Bentley } \\
\text { - Moderate inward TCA influence on } \\
\text { local agreements \& outcomes } \\
\text {-Moderate outward influence on } \\
\text { international subsidiaries via } \\
\text { international union coordination }\end{array}$ & $\begin{array}{l}\text { G4S } \\
\text { - Moderate inward TCA influence } \\
\text { on local agreements \& outcomes } \\
\text { - Moderate outward influence on } \\
\text { international subsidiaries via } \\
\text { international union coordination }\end{array}$ \\
\hline
\end{tabular}

These workplace-level power resources were not present in G4S but the formalized, co-ordinated institutional structures deriving from the IFA and direct access to headquarter management meant that union influence was again relatively high in this case. Where workplace- and firm-level industrial relations institutions, including union organization, were less co-ordinated, as in Santander and Unilever, access to headquarter management became more important. This access was lacking in the case of Santander, the weakest of the four cases, and the lack of institutional co-ordination in the Unilever case meant that the direct but informal access that unions had gained with headquarter management became more significant in terms of union influence.

The local impact of TCAs was highly varied; in the 'stronger' VW-Bentley case, more consultative management styles had been developed in line with the ethos of the TCAs, UK representatives had been active in supporting other unions in the firm's global operations and tangible results were visible in ensuring that investment was maintained in the UK rather than overseas plants, opening up new institutional spaces and roles for local trade unionists despite arguably reinforcing national competition within the MNC's workforce. In Santander, the European-level TCAs had a more marginal impact but notable changes including more consultative management styles were apparent, along with the development of networks between trade unionists in the UK and elsewhere, particularly Spain. Attempts to invoke the TCA had been problematic, and firm structure and multiunionism militated against the development of a more encompassing IFA. The G4S case demonstrated a relatively robust relationship between the GMB and the firm with the wider IFA referenced in bargaining processes to hold the firm to account. While more adversarial approaches to union organizing had been adopted by the SEIU in G4S compared to the GMB, and were crucial in initially securing the IFA, the institutional formations surrounding the agreement and the role of the EWC allowed for pressures related to campaigning to be applied on the company in less overt ways. 
In Unilever, TCAs signed by the EWC had a modest effect on industrial relations in the UK but there was considerable involvement of UK-based representatives within international campaigns run by the GUF and regular meetings between the GUF and headquarter level management. This less formalized approach had a limited impact on the UK situation but allowed for significant levels of involvement in international campaigning, which in turn created new local dialogue between segments of Unilever in the UK that partly compensated for the formal institutional gaps that exist. Given the prevalence of antiunionism in the UK (Gall 2013), actual and threatened union de-recognition in the Santander and G4S cases and the difficulties of enforcing the content of agreements, key individuals supported by unions made significant use of developing transnational networks and power resources in the manner of 'political entrepreneurs' identified elsewhere (Greer and Hauptmeier 2008). These networks and resources were in turn referenced within localized relations.

Concluding that TCAs are often underused (McCallum 2013), have a weak local application (Niforou 2012) and that institutional structures supporting them have inherent weaknesses (Waddington 2011;Wills 2000) may naturally follow from such findings given the lack of coordination of international activity as well as the complexity of MNCs. Yet TCAs should be understood as part of a 'portfolio' of diverse resources, strategies and institutional relations, and exploring these in detail raises numerous questions about how internationalism is framed in practice and within local spaces by different industrial relations actors. Distinctions between 'rights' and 'rules' deriving from TCAs (Fichter and McCallum 2015; McCallum 2013) are important, and 'hard', enforceable rights deriving from TCAs were evidently limited. In many cases they did, however, appear to have a wider impact on the legitimacy and renewed activities of unions within MNCs, procedural structures, levels of consultation between management and workforce and other less tangible benefits that go beyond the clauses included within the texts of TCAs. The impact of such agreements on these 'rules of engagement' was evident in the first three cases. While Unilever had been influenced by the campaigning approach adopted by the IUF, the separate nature of EWC agreements in the firm meant that such international activity had a modest impact on industrial relations in the UK compared to the other cases, although informal links and networks were evolving nonetheless. While tensions remain between such campaigning approaches in relation to more established bargaining rights and union-employer relations, the less institutionalized role of labour within Unilever meant there was less to be lost by engaging in such activity.

The co-ordination of multi-level employee representative bodies and their respective power resources, including local union orientations, access to headquarters, union-GUF links, EWC characteristics and leverage within corporate structures are key determinants of the overall impact of TCAs (Da Costa et al. 2012; Keune and Marginson 2013; Williams et al. 2013). Institutional power and the access TCAs facilitated with MNC headquarters were important; strong workplace union cultures as seen in VW-Bentley, deriving from traditions of engineering trade unionism were also significant, and the lack of this in the other three cases meant the integration of TCAs more locally was less apparent. Even in cases where institutional structures were weaker, as in Unilever, or dispersed over a highly fragmented workforce, as in G4S, formalized institutions such as EWCs, GUFs and TCAs were referenced and used (albeit in piecemeal ways, with agreements often dormant and invoked around particular disputes) within broader combinations of strategies. This was assisted by the headquartering of these two cases within the UK which allowed for on-going informal relations and dialogue to embed themselves.

Unilever covered a wide range of organizations and hard to reach workforces while G4S was involved in a sector which led to highly sensitive questions of rights and political developments in terms of its services. Developments in both of these firms, including the G4S IFA, were a direct result of worker mobilization and conflict (see also Croucher and Cotton 2011; Kotthoff andWhittall 2014; McCallum 2013). An emphasis on 'conflict partnership' (Fichter and McCallum 2015) has been 
highlighted as necessary within the implementation of TCAs; conflictual approaches were problematic, and were felt in the case of G4S to be counterproductive in some respects. Strategic combinations incorporating campaigning approaches that challenge multinationals while enhancing the rights, rules and power resources of unions more locally are contradictory and difficult to sustain. However, the more dispersed and informal institutional status of unions in the UK ironically opened up spaces within which unions could address such divergent strategic concerns. Local, more informal union organization was able to engage with external MNC developments and vulnerabilities as a basis for the development of international strategies that could use the rule-making processes associated with TCAs as a means of strengthening collective rights within MNCs more directly.

\section{Conclusion}

TCAs are not automatically enforced, referenced or known by industrial relations actors, especially management (Niforou 2012). Addressing these issues is a challenge but necessary if such international approaches are to be deepened and widened (Sydow et al. 2014). Transnational agreements are part of a broader process of engagement and trade union strategy. This is dependent on the orientations, internal resources and historical development of unions, the nature of their international activity, approaches to campaigning and their politics. Strengthened union influence deriving from TCAs within MNCs is in part dependent on the co-ordination of firm-level institutional power resources held (both formally and informally) by unions, union engagement with EWCs and GUFs, and union access to headquarter management. However, the relatively strong institutional presence held by some unions meant they had more to lose by adopting openly critical campaigning tactics which have otherwise proved to be effective in forcing MNCs to change their actions. The particular nature and structure of individual MNCs, while constraining in many respects, can create spaces within which labour can apply pressure on management in a broader sense than implied within the formal framework of TCAs.

Analysis of new international agreements and processes therefore requires sensitivity to the political, the local and the informal. The rights contained in an agreement are only a small part of the wider picture; how they become part of a portfolio of social, industrial and political strategies, relations within and between trade unions, relationships with employers and processes of rule-making, in subtle, varied and more diverse ways, is crucially important (Brookes 2013; Fichter and McCallum 2015). Analysing the cases in a way that encompasses more informal aspects of industrial relations (Clegg 1976; Terry 1977) and networking-related activities (Martínez Lucio and Weston 1995) addresses the question of how TCAs are invoked, either directly or indirectly, within national and more local union activity in relation to inward, national and outward, international union action and relations through a range of union actors and groups. This raises significant methodological issues, including the importance of qualitative and inductive research to avoid a blinkered, one-dimensional institutionalist view which dissects and isolates relations associated with TCAs and dismisses their less direct, more informal impact. International agreements and structures were viewed as levers of influence and opportunities - as resources - which could provide reference points and spaces to develop international links at critical moments, and not just predetermined forms of social dialogue or partnership, even in the UK context where high trust regulatory processes and statutory support for collective bargaining are relatively absent. 


\section{Acknowledgements}

The authors would like to thank Virginia Doellgast, the two anonymous reviewers, Salvo Leonardi and the support of the EURACTA 2 project for the VW-Bentley and Santander cases.

\section{References}

Anner, M., Greer, I., Hauptmeier, M., Lillie, N. and Winchester, N. (2006). 'The industrial determinants of transnational solidarity: global interunion politics in three sectors'. European Journal of Industrial Relations, 12 (7): 7-27.

Banyuls, J., Haipeter, T. and Neumann, L. (2008). 'European Works Council at General Motors Europe: bargaining efficiency in regime competition'. Industrial Relations Journal, 39 (6): 532-47.

Batstone, E., Boraston, I. and Frenkel, S. (1977). Shop Stewards in Action: The Organization of Workplace Conflict and Accommodation. Oxford: Blackwell.

Brookes, M. (2013). 'Varieties of power in transnational labor alliances: an analysis of workers' structural, institutional, and coalitional power in the global economy'. Labor Studies Journal, 38 (3): 181-200.

Clegg, H. (1976). Trade Unionism under Collective Bargaining: A Theory Based on Comparisons of Six Countries. Oxford: Blackwell.

Croucher, R. and Cotton, E. (2011). Global Unions, Global Business: Global Union Federations and International Business. Faringdon: Libri.

Da Costa, I., Pulignano, V., Rehfeldt, U. and Telljohann, V. (2012). 'Transnational negotiations and the Europeanization of industrial relations: potential and obstacles'. European Journal of Industrial Relations, 18 (2): 123-37.

Darlington, R. (2002). 'Shop stewards' leadership, left-wing activism and collective workplace union organisation'. Capital \& Class, 26 (1): 95-126.

Fichter, M. and Helfen, M. (2011). 'Going local with global policies: implementing international framework agreements in Brazil and the United States'. In K. Papadakis (ed.), Shaping Global Industrial Relations: The Impact of International Framework Agreements. Basingstoke: Palgrave Macmillan.

— and McCallum, J. (2015). 'Implementing global framework agreements: the limits of social partnership'. Global Networks, 15 (s1): S65-S85.

Gall, G. (2013). 'Employers against unions: the British experience of union victimisation'. In G. Gall and T. Dundon (eds.), Global Anti-Unionism: Nature, Dynamics, Trajectories and Outcomes. London: Palgrave Macmillan.

Greer, I. and Hauptmeier, M. (2008). 'Political entrepreneurs and co-managers: labour transnationalism at fourmultinational auto companies'. British Journal of Industrial Relations, 46 (1): 76-97.

and - (2012). 'Identity work: sustaining transnational collective action at General Motors Europe'. Industrial Relations: A Journal of Economy and Society, 51 (2): 275-99. 
Gregoratti,C. and Miller,D. (2011). 'International framework agreements for workers' rights? Insights from River Rich Cambodia'. Global Labour Journal, 2 (2): 84-105.

Hammer, N. (2005). 'International framework agreements: global industrial relations between rights and bargaining'. Transfer, 15 (1): 511-30.

Helfen, M. and Fichter, M. (2013). 'Building transnational union networks across global production networks: conceptualising a new arena of labour-management relations'. British Journal of Industrial Relations, 51 (3): 553-76.

Jensen, T. (2004). 'The networking arena'. In T. Jensen and A. Westenholz (eds.), Identity in the Age of the New Economy: Life in Temporary and Scattered Work Practices. Cheltenham: Edward Elgar.

Joyce, S. (2016). 'Revisiting Shop Stewards and Workplace Bargaining: Opportunities, Resources and Dynamics in Two Case Studies'. PhD Thesis, University of Hertfordshire.

Keune, M. and Marginson, P. (2013). 'Transnational industrial relations as multilevel governance: interdependencies in European social dialogue'. British Journal of Industrial Relations, 51 (3): 47397.

Knudsen, H.,Whittall, M. and Huijgen, F. (2007). 'European Works Councils and the problem of identity'. In M. Whittall, H. Knudsen and F. Hujigen (eds.), Towards a European Labour Identity: The Case of European Works Councils. London: Routledge.

Kotthoff, H. and Whittall, M. (2014). Paths to Transnational Solidarity: Identity-Building Processes in European Works Councils. Brussels: Peter Lang.

Leonardi, S. (ed.) (2015). EURACTA 2: Transnational Company Agreements: Experiences and Prospects - Final Report. Rome: Associazione Bruno Trentin.

Martínez Lucio, M. and Weston, S. (1995). 'Trade unions and networking in the context of change: evaluating the outcomes of decentralization in industrial relations'. Economic and Industrial Democracy, 16 (2): 233-51.

— and (2000). 'European Works Councils and flexible regulation: the politics of intervention'. European Journal of Industrial Relations, 6 (2): 203-16.

McCallum, J. (2013). Global Unions, Local Power: The New Spirit of Transnational Labor Organizing. Ithaca, NY: Cornell University Press.

Niforou, C. (2012). 'International Framework Agreements and industrial relations governance: global rhetoric versus local realities'. British Journal of Industrial Relations, 50 (2): 352-73.

Oxenbridge, S. and Brown, W. (2002). 'The two faces of partnership? An assessment of partnership and co-operative employer/trade union relationships'. Employee Relations, 24 (3): 262-76.

Pulignano, V. (2005). 'EWCs' cross-national employee representative coordination: a case of trade union cooperation?' Economic and Industrial Democracy, 26 (3): 383-412.

(2009). 'International cooperation, trans-national restructuring and virtual networking in Europe'. European Journal of Industrial Relations, 15 (2): 183-201. 
Rehfeldt, U. (2015). 'Transnational company agreements: a map'. In S. Leonardi (ed.), Transnational Company Agreements: Experience and Prospects: Final Report. Rome: Associazione Bruno Trentin.

Schömann, I., Sobczak, A., Voss, E. and Wilke, P. (2008). 'International framework agreements: new paths to workers' participation in multinationals' governance?' Transfer, 14 (1): 111-26.

Stevis, D. (2011). 'The impacts of International Framework Agreements: lessons from the Daimler case'. In K. Papadakis (ed.), Shaping Global Industrial Relations: The Impact of International Framework Agreements. Basingstoke: Palgrave Macmillan.

and Boswell, T. (2007). 'International Framework Agreements'. In K. Bronfenbrenner (ed.), Global Unions: Challenging Transnational Capital through Cross-Border Campaigns. Ithaca, NY: ILR Press.

Sydow, J., Fichter,M., Helfen,M., Sayim, K. Z. and Stevis,D. (2014). 'Implementation of Global Framework Agreements: towards a multi-organizational practice perspective'. Transfer, 20 (4): 489503.

Terry, M. (1977). 'The inevitable growth of informality'. British Journal of Industrial Relations, 15 (1): 76-90.

Waddington, J. (2011). 'European Works Councils: the challenge for labour.' Industrial Relations Journal, 42 (6): 508-29.

Whittall, M. (2010). 'The problem of national industrial relations traditions in European Works Councils: the example of BMW'. Economic and Industrial Democracy, 31 (4): 70-85.

- Knudsen,H. and Huijgen, F. (2009). 'European Works Councils: identity and the role of information and communication technology'. European Journal of Industrial Relations, 15 (2): 16785.

Williams, G., Davies, S. and Chinguno, C. (2013). 'Subcontracting and labour standards: reassessing the potential of International Framework Agreements'. British Journal of Industrial Relations, 53 (2): 181-203.

Wills, J. (2000). 'Great expectations: three years in the life of a European Works Council'. European Journal of Industrial Relations, 6 (1): 85-108. 